\title{
Addiction Teaching and Training in the General Psychiatry Setting
}

\author{
Sandra M. DeJong ${ }^{1}$ - Alëna A. Balasanova ${ }^{2}$ - Amber Frank ${ }^{1}$. Anne E. Ruble ${ }^{3}$ - Julia R. Frew ${ }^{4}$ - Michael Hoefer ${ }^{5}$. \\ Daniela B. Rakocevic ${ }^{6} \cdot$ Theadia Carey $^{7} \cdot$ John A. Renner ${ }^{8} \cdot$ Ann C. Schwartz $^{9} \mathbb{C}$
}

Received: 22 October 2020 / Accepted: 24 February 2021 / Published online: 11 March 2021

(C) Academic Psychiatry 2021

Over 20.1 million Americans have a substance use disorder (SUD) of whom only $6.9 \%$ receive treatment [1]. One in seven people in the USA develops a SUD over the course of their lifetime [2]. According to the 2018 National Survey on Drug and Health, 3.2 million people had both a SUD and serious mental illness (SMI) within the past year [3].

While almost $20 \%$ of patients with psychiatric disorders suffer from a co-occurring SUD, psychiatric training guidelines require only $2 \%$ of psychiatric residency (i.e., 1 month out of 4 years) be spent learning how to treat addictions [3, 4]. This is the largest disparity between illness prevalence and training commitment in psychiatry residency, a disparity which may be influenced by the historical stigmatization of this patient population. Training barriers include lack of faculty with addiction expertise, limited access to different levels of care for rotation sites, and the time and effort required to change pre-existing rotation schedules [5-7]. In the face of a national crisis in opioid misuse and other addiction treatment, access to care remains compromised by insufficient physicians willing and able to treat addictions [4]. While subspecialists have a critical role to play, there are too few addictiontrained psychiatrists to handle this crisis alone. Education in addictions should be a core domain of psychiatric residency

Ann C. Schwartz

aschwa2@emory.edu

Cambridge Health Alliance, Cambridge, MA, USA

University of Nebraska Medical Center, Omaha, NE, USA

Johns Hopkins Medical Institutions, Baltimore, MD, USA

4 Dartmouth Geisel School of Medicine, Hanover, NH, USA

5 University of California, San Francisco, CA, USA

6 Northwestern University Feinberg School of Medicine, Chicago, IL, USA

7 Authority Health GME, Detroit, MI, USA

8 Boston University, Boston, MA, USA

9 Emory University School of Medicine, Atlanta, GA, USA training to ensure that residents have necessary competence to fulfill clinical and workforce needs.

In 2017, the American Association of Directors of Psychiatric Residency Training (AADPRT) Taskforce on Addictions was created to try to improve addiction training in psychiatry [6]. The Taskforce's needs assessment survey of general psychiatry training directors found that, while most programs indicated they have addiction-trained faculty, programs still feel under-resourced. Faculty pressures such as productivity demands contribute to difficulties in addictiontrained faculty meeting the educational needs of an understaffed institution. A majority of respondents sought educational resources [6].

In this manuscript, we provide a model of how to recognize addiction learning opportunities already present in the general training environment and develop successful educational experiences to maximize such opportunities. The ultimate goal of addiction training in general psychiatry settings is to develop an appropriate knowledge base to treat patients with SUD confidently and compassionately, foster a positive attitude toward patients with SUDs and the benefits of treatment, and establish a sense of responsibility toward substance use as a clinical problem within every psychiatrist's domain [8]. By identifying and drawing upon learning opportunities within the general training environment, programs can augment their existing addiction education and meet these goals successfully.

\section{Core Interviewing Skills}

Core skills in addictions for general psychiatry residents are summarized in Table $1[9,10]$. Core interviewing skills can be taught in various settings, including general outpatient, inpatient, emergency department, and consultation-liaison (CL) services. Identification and screening for SUDs is a key first step in teaching residents to conduct a comprehensive substance use history. While all patients should be routinely 
Table 1 Core skills in addictions for general psychiatry residents

\begin{tabular}{|c|c|c|}
\hline Core skills & What to teach & Resources \\
\hline Diagnostic interview & $\begin{array}{l}\text { Diagnostic criteria } \\
\text { Alliance building } \\
\text { Non-stigmatizing language } \\
\text { Core components of substance history: } \\
\text { substances used, route of } \\
\text { administration, frequency, problems } \\
\text { experienced, withdrawal symptoms, } \\
\text { treatment history }\end{array}$ & $\begin{array}{l}\text { Diagnostic and Statistical Manual of Mental Disorders, } \\
\text { Fifth Edition (DSM-5) [9] } \\
\text { American Psychiatric Association (APA) Practice guideline } \\
\text { for the treatment of patients with substance use } \\
\text { disorders, 2nd ed. [10] } \\
\text { Substance Abuse and Mental Health Services Administration } \\
\text { (SAMHSA) guidance on language and stigma: } \\
\text { https://www.samhsa.gov/sites/default/files/programs_campaigns/02._webcast_1_ } \\
\text { resources-508.pdf } \\
\text { National Institute on Drug Abuse (NIDA) guidance } \\
\text { on language and stigma: https://www.drugabuse. } \\
\text { gov/nidamed-medical-health-professionals/health-professions-education/words- } \\
\text { matter-terms-to-use-avoid-when-talking-about-addiction }\end{array}$ \\
\hline $\begin{array}{l}\text { SUD screening: broad } \\
\text { screening for SUDs }\end{array}$ & $\begin{array}{l}\text { Screening to Brief Intervention (S2BI, } \\
\text { adolescents) } \\
\text { NIDA Drug Use Screening Tool: } \\
\text { Quick Screen (NMASSIST) } \\
\text { Tobacco, Alcohol, Prescription } \\
\text { Medicine and Other Substance Use } \\
\text { (TAPS) } \\
\text { Brief Screener for Alcohol, Tobacco } \\
\text { and Other Drugs (BSTAD) }\end{array}$ & $\begin{array}{l}\text { Screening and Assessment Tools Chart (NIDA): https:/www.drugabuse. } \\
\text { gov/nidamed-medical-health-professionals/screening-tools-resources/chart-screening-tools } \\
\text { APA adapted NIDA Modified Alcohol, Smoking and } \\
\text { Substance involvement Screening Test } \\
\text { (ASSIST) tools: https://www.drugabuse.gov/nidamed-medical-health-professionals } \\
\text { /screening-tools-resources/american-psychiatric } \\
\text {-association-adapted-nida-modified-assist-tools } \\
\text { (for clinician- and self- administration) } \\
\text { Tools to assist in integrating tobacco treatment into } \\
\text { clinical care: https://www.cdc.gov/tobacco/basic_- } \\
\text { information/for-health-care-providers/clinical-tools/index.html }\end{array}$ \\
\hline $\begin{array}{l}\text { SUD screening: focused } \\
\text { screening for specific } \\
\text { substances }\end{array}$ & $\begin{array}{l}\text { Alcohol Use Disorders Identification } \\
\text { Test (AUDIT-C) } \\
\text { Cannabis Use Disorder Identification } \\
\text { Test - Revised (CUDIT-R) } \\
\text { Tobacco use protocol }\end{array}$ & $\begin{array}{l}\text { AUDIT-C screening tool: https://cde.drugabuse. } \\
\text { gov/instrument/f229c68a-67ce-9a58-e040-bb89ad432be4 } \\
\text { CUDIT-R screening tool: http://mycannabisiq.ca/portfolio/cudit-r-revised-2010/ } \\
\text { Protocol for Identifying and Treating Patients Who Use Tobacco: } \\
\text { https://millionhearts.hhs. } \\
\text { gov/files/Tobacco-Cessation-Protocol.pdf }\end{array}$ \\
\hline $\begin{array}{l}\text { Appropriate use of an } \\
\text { interpretation } \\
\text { of laboratory testing }\end{array}$ & $\begin{array}{l}\text { Measures of intoxication (blood } \\
\text { alcohol level, breathalyzer) } \\
\text { Urine drug screen }\end{array}$ & $\begin{array}{l}\text { ASAM Consensus Statement: Appropriate Use of Drug Testing in } \\
\text { Clinical Addiction Medicine: } \\
\text { https://www.asam.org/docs/default-source/quality-science/appropriate_use_of_drug } \\
\text { testing_in_clinical-1-(7).pdf?sfvrsn=2 } \\
\text { ASAM Drug Testing Pocket Guide: http://eguideline.guidelinecentral. } \\
\text { com/i/840070-drug-testing-pocket-guide/31 } \\
\text { Clinical Interpretation of Urine Drug Tests: https://www.mayoclinicproceedings. } \\
\text { org/article/S0025-6196(1630825-4/fulltext }\end{array}$ \\
\hline $\begin{array}{l}\text { Identifying and managing } \\
\text { other co-occurring psychi- } \\
\text { atric disorders }\end{array}$ & $\begin{array}{l}\text { Recognizing co-occurring mood, } \\
\text { psychotic, attentional, and other } \\
\text { disorders }\end{array}$ & $\begin{array}{l}\text { SAMHSA Tip 42: Substance Use Treatment for Persons } \\
\text { with Co-Occurring Disorders: } \\
\text { https://store.samhsa.gov/product/tip-42-subs } \\
\text { tance-use-treatment-persons-co-occurring-disorders/PEP20-02-01-004 }\end{array}$ \\
\hline $\begin{array}{l}\text { Identifying and managing } \\
\text { co-occurring medical } \\
\text { disorders }\end{array}$ & $\begin{array}{l}\text { Narcotic bowel syndrome } \\
\text { Negative effects of tobacco } \\
\text { Pain } \\
\text { Bacterial and viral infections in } \\
\quad \text { people who use substances }\end{array}$ & $\begin{array}{l}\text { NIDA Notes: Substance Use Disorders Associated with Major } \\
\text { Medical Illnesses and Mortality } \\
\text { risk: https://www.drugabuse. } \\
\text { gov/news-events/nida-notes/2017/10/substance-use-disorders-are-as } \\
\text { sociated-major-medical-illnesses-mortality-risk-in-large-integrated\#: :text= } \\
\text { PatientsWithSubstanceUseDisorders,oranySUDthanin } \\
\text { Providers Clinical Support System (PCSS) module on } \\
\text { Medical Considerations } \\
\text { for Patients with Opioid Use Disorder: } \\
\text { https://learning.pcssnow.org/p/MedicalConsiderations }\end{array}$ \\
\hline $\begin{array}{l}\text { Management of intoxication, } \\
\text { overdose, and withdrawal }\end{array}$ & $\begin{array}{l}\text { Alcohol } \\
\text { Opioids } \\
\text { Other substances }\end{array}$ & $\begin{array}{l}\text { ASAM Alcohol Withdrawal Management Guideline: } \\
\text { https:/www.asam.org/Quality-Science/quality/guideline-on-alcohol-withdrawal-management } \\
\text { PCSS module on Management of Opioid Overdose and } \\
\text { Withdrawal: https://pcssnow. } \\
\text { org/education-training/training-courses/management-opioid-withdrawal-overdose/ }\end{array}$ \\
\hline $\begin{array}{l}\text { Brief motivational } \\
\text { interventions } \\
\text { and stages of change }\end{array}$ & $\begin{array}{l}\text { Engaging the patient } \\
\text { Focusing } \\
\text { Evoking } \\
\text { Planning using OARS: } \\
\text { Open questions, Affirming, Reflection } \\
\quad \text { (a listening response), Summarizing } \\
\text { Relapse prevention }\end{array}$ & $\begin{array}{l}\text { Motivational Interviewing Network of Trainers (MINT): } \\
\text { https://motivationalinterviewing.org/ } \\
\text { Rosengren DB. Building Motivational Interviewing Skills: A } \\
\text { Practitioner Workbook. 2nd } \\
\text { ed. New York: The Guilford Press; } 2018 \text { [12] }\end{array}$ \\
\hline
\end{tabular}


Table 1 (continued)

\begin{tabular}{|c|c|c|}
\hline Core skills & What to teach & Resources \\
\hline Harm reduction strategies & $\begin{array}{l}\text { Opioid overdose prevention } \\
\text { Diversion prevention } \\
\text { Needle exchange programs } \\
\text { Educational/vocational training } \\
\text { Suicide prevention } \\
\text { Resources related to interpersonal } \\
\quad \text { violence } \\
\text { Resources related to housing insecurity } \\
\quad \text { and other social determinants of } \\
\text { health }\end{array}$ & $\begin{array}{l}\text { SAMHSA Opioid Overdose Prevention Toolkit: https://store.samhsa. } \\
\text { gov/product/Opioid-Overdose-Prevention-Toolkit/SMA18-4742 } \\
\text { Canadian resource on safe consumption: } \\
\text { https://www.canada. } \\
\text { ca/en/health-canada/services/substance-use/supervised-consumption-sites.html } \\
\text { Centers for Disease Control and Prevention (CDC) resource } \\
\text { on syringe service programs } \\
\text { : https://www.cdc.gov/ssp/syringe-services-programs-faq.html } \\
\text { National Domestic Violence Hotline: https:/www.thehotline.org }\end{array}$ \\
\hline Behavioral interventions & $\begin{array}{l}\text { Motivational enhancement } \\
\text { therapy } \\
\text { Cognitive behavioral therapy } \\
\text { Contingency } \\
\text { management/reinforcement approach }\end{array}$ & $\begin{array}{l}\text { Combining Medications and Behavioral } \\
\text { Interventions (COMBINE) I Combined } \\
\text { Behavioral Intervention } \\
\text { - Therapist Manual v 4.0: } \\
\text { https://web.3rdmil.com/assets/guides/research/Miller-CombinedBehavioralIntervention } \\
\text { ThearpistManual.pdf }\end{array}$ \\
\hline $\begin{array}{l}\text { Mutual and self-help organi- } \\
\text { zations }\end{array}$ & $\begin{array}{l}\text { 12-Step: } \\
\text { Alcoholics Anonymous, Narcotics } \\
\text { Anonymous, Help Guide: } \\
\text { Overcoming } \\
\text { Alcohol Addiction, American } \\
\text { Addiction Centers } \\
\text { Non-12-Step: } \\
\text { SMART Recovery, Women for } \\
\text { Sobriety, } \\
\text { Lifering, Recovery Dharma, } \\
\text { Intherooms }\end{array}$ & $\begin{array}{l}\text { 12-Step resources: } \\
\text { www.aa.org/pages/en_US/find-aa-resources } \\
\text { www.na.org/meetingsearch } \\
\text { https://www.helpguide.org/articles/addictions/drug-abuse-and-addiction.htm } \\
\text { Non-12-Step resources: } \\
\text { https://www.smartrecovery.org/ } \\
\text { https://womenforsobriety.org/ } \\
\text { https://www.lifering.org/ } \\
\text { https://recoverydharma.online/ } \\
\text { https://www.intherooms.com/home/ }\end{array}$ \\
\hline $\begin{array}{l}\text { Medications for addiction } \\
\text { treatment (MAT) }\end{array}$ & $\begin{array}{l}\text { Buprenorphine waiver training } \\
\text { Medications for opioid use disorder } \\
\text { (MOUD) and alcohol use disorder } \\
\text { (MAUD) }\end{array}$ & $\begin{array}{l}\text { PCSS Waiver Training for Physicians: } \\
\text { https://pcssnow.org/medication-assisted-treatment/waiver-training-for-physicians/ } \\
\text { PCSS module on Medications for Addiction Treatment: } \\
\text { https://pcssnow.org/education-training/training-courses/supporting-recovery-with-me } \\
\text { dications-for-addiction-treatment-mat/ } \\
\text { PCSS module on Pharmacotherapy for Alcohol Use Disorder: } \\
\text { https://learning.pcssnow.org/p/PharmacotherapyForAUD } \\
\text { PCSS module on Medications for Opioid Use Disorder: https://learning.pcssnow. } \\
\text { org/p/MedicationforOUD }\end{array}$ \\
\hline $\begin{array}{l}\text { Determining appropriate } \\
\text { level of care }\end{array}$ & $\begin{array}{l}\text { Appropriate level of care for patient } \\
\text { needs and existing resources }\end{array}$ & $\begin{array}{l}\text { American Society of Addiction Medicine (ASAM) Criteria: } \\
\text { https://www.beaconhealthoptions.com/pdf/members/Introduction-to-The-ASM } \\
\text {-Criteria-for-Patients-and-Families.pdf } \\
\text { https://www.asamcontinuum.org/knowledgebase/what-are-the-six-dimensions } \\
\text {-of-the-asam-criteria/ } \\
\text { https://www.asam.org/asam-criteria/about } \\
\text { https://www.asamcontinuum.org/knowledgebase/what-are-the-asam-levels-of-care/ }\end{array}$ \\
\hline $\begin{array}{l}\text { Engaging families and } \\
\text { patient's organic support } \\
\text { system }\end{array}$ & $\begin{array}{l}\text { Identifying and engaging support } \\
\text { system } \\
\text { Identifying appropriate roles while } \\
\text { respecting confidentiality } \\
\text { Working with peer support specialists } \\
\text { if available }\end{array}$ & $\begin{array}{l}\text { Parents of Addicted Loved Ones: https://palgroup.org/ } \\
\text { National Association for Children of Addictions: https://nacoa.org/ } \\
\text { International Association of Peer Supporters: https://www.inaops.org/ }\end{array}$ \\
\hline
\end{tabular}

screened for alcohol and drug use, potential barriers such as limited time and negative clinician countertransference can impede this assessment [11]. Fortunately, residents can learn strategies to enhance the therapeutic alliance and improve the accuracy of patients' self-report regarding substance use.

Residents should begin by assessing the use of less stigmatized substances such as nicotine and caffeine, followed by alcohol, to establish an initial level of comfort before moving on to illicit substance use. A comprehensive substance use history should include substances used, route of administration, frequency of use, problems experienced, withdrawal symptoms, and history of SUD treatments, including both medication and psychosocial treatments. Patients should also be asked about non-medical use of medications or use of overthe-counter or prescription drugs in any way other than prescribed. Questions about substance use should be asked nonjudgmentally, for example asking about "recreational" or "social" use of substances rather than "illicit" use of drugs. 
Cannabis carries less social stigma than other drugs, and patients are often more willing to openly discuss their cannabis use. In fact, providers may need to ask about cannabis use specifically, since many individuals may not consider cannabis a drug when asked about drug use.

Including language that normalizes substance use can help. Rather than asking, "Do you drink alcohol?" the resident might ask, "How many drinks per day do you drink?" or "In the past year, how many times have you used x?" If a patient endorses use of a substance, open-ended follow-up questions might include, "How do you feel about your X use?," "What is it that you like about X?," or "What do you not like about $\mathrm{X}$ ?" If patients appear guarded, normalizing substance use and communicating universal screening as part of clinic policy may help alleviate stigma concerns and fears of resulting suboptimal medical care. Patients may also need to be educated that substance use is an important aspect of their psychiatric history and that effective interventions are available from their psychiatrist to help treat or reduce harm from substance use. Even patients successfully in recovery on buprenorphine or methadone may sometimes not disclose this information in the emergency department for fear they will be denied needed analgesia for acute pain syndromes.

Motivational interviewing (MI) is a critical skill to learn and to practice in working with patients with SUD and is a logical next step as the trainee masters the fundamentals of acquiring a comprehensive substance use history. MI may be taught by addiction-certified physician faculty; residents also can gain important exposure to a variety of MI strategies through observation of interdisciplinary colleagues, such as social workers and psychologists. Core MI topics to include in resident education include the overarching "RULE" principles (Resist the righting reflex, Understand the patient's motivation, Listen with empathy, and Empower the patient) as well as demonstration of specific language and alliance [12]. MI education can also occur outside of the addiction rotation, for example as part of general psychiatric interviewing or psychotherapy didactics series. Highlighting the applicability of this core skill to work with patients of all backgrounds, even those without SUD, can help promote resident engagement.

"Harm reduction" is an approach to care that is central to meeting patients wherever they may be at on their recovery journey. Historical addiction treatment has focused primarily on promoting complete abstinence from substance use. Harm reduction recognizes that cessation of substance use is only one of many worthy goals of treatment and reducing substance-related harm to individuals, their families, and communities is an important target. In contrast to typically prescriptive and proscriptive medical care, harm reduction posits a non-judgmental attitude to drug and alcohol use. Examples of large-scale harm reduction strategies include syringe exchange programs and opioid treatment programs, colloquially known as methadone clinics [13].
Residents will need to learn that clinical features, social factors, and professional biases can contribute to underrecognition of SUD in specific populations. For example, adolescents, perinatal women, and geriatric patients may be less likely to be screened for substance use due to assumptions that these groups are less likely to use substances. In the geriatric population, SUDs may be challenging to identify because symptoms of alcohol and drug use can resemble illnesses common in later life, and this population many have difficulty identifying their risky substance-related behaviors $[11,14]$.

Screening instruments can be helpful tools when used as an adjunct resource to support obtaining a comprehensive substance use history. No specific screening instruments for SUD have consensus support in psychiatry as most were developed for primary care populations and lack data on sensitivity/ specificity in psychiatric populations. Standardized assessment tools can help provide psychiatric residents with a useful structure and introductory vocabulary for assessing substance use (see Table 1).

\section{Stigma}

Unlike schizophrenia or major depressive disorder, SUD has historically been viewed as a moral failing and social problem rather than a chronic mental illness. Although the Diagnostic and Statistical Manual of Mental Disorders, Fifth Edition (DSM-5) devotes an entire chapter to "Substance-related and addictive disorders," treatment of SUDs often remains siloed from mainstream mental healthcare [9]. Negative attitudes toward patients with SUDs begin in medical school [15] and increase through residency and professional practice $[16,17]$. This decline has been explained in part by residents having most exposure to SUDs in acute care settings such as inpatient units or emergency services when patients are usually at their functional nadir [18].

Language related to SUD shapes attitudes among healthcare professionals. Commonly used terms like "substance abuse" and "drug abuser" explicitly and implicitly convey that patients are at fault for their disease [19]. Stigmatizing terminology such as "alcoholism" and "addict" has been shown to negatively impact physician attitudes and compromise patient care [20,21]. Negative attitudes among healthcare professionals regarding patients with SUD are linked with reduced empathy and engagement with patients, reduced delivery of evidence-based treatment services, and poorer patient outcomes [21].

To reduce the stigma associated with SUD, the US Surgeon General's lexicon of nonjudgmental and clinically accurate preferred terms such as "substance use," "misuse," and "substance use disorder" are advised [2]. Avoidance of terms like "addict" or "drug user" and instead encouraging person-first language such 
as "person with a SUD" is recommended. In addition, terms such as "clean" or "dirty" to describe drug testing results or a person using substances should be avoided; describing the drug test as "positive" or "negative" for a substance or the person as "using" or "not using" the substance is preferable.

Most required addiction rotations are short term (typically 1 month) and take place in high-acuity settings including the emergency room, consult services, or inpatient units [18, 22] where patients may only be pre-contemplative about treatment. Residents may become discouraged and develop an impression that patients with SUDs are resistant to help. Such negative attitudes should be addressed directly. Trainees may need anti-stigma and implicit bias awareness education to work through their countertransference. Sequential reflective narrative exercise is an example of a potential activity.

Field trips in the community to develop familiarity with local addiction resources can also combat stigma. In-person contact with patients in recovery such as attending Alcoholics Anonymous (AA) meetings challenges learners' negative perceptions, broadens their understanding of SUDs, and also improves attitudes [23].

\section{Teaching About Addictions in General Settings}

The prevalence of SUDs in all clinical settings gives trainees opportunity to learn about addictions across the spectrum of care. Table 2 outlines the challenges and opportunities for teaching about SUDs in the most common training settings, including outpatient rotations that offer unique educational benefits relative to acute care settings. Working longitudinally with patients with SUD over the trajectory of their chronic illness allows trainees to see treatment work, increasing the likelihood they may consider SUD treatment as part of their future practice $[5,18]$.

Within these settings, residents should gain experience and familiarity with medications for addiction treatment (MAT) for tobacco, alcohol, and opioid use disorder (OUD). Of note, the acronym MAT previously stood for medication-assisted treatment, but now refers to medications for addiction treatment. This new acronym reflects a shift in understanding within addiction psychiatry in recent years toward acknowledging the more central role and efficacy medications can have for some SUD patients.

Buprenorphine is an approved MAT agent that been transformative for outpatient OUD treatment. An integral part of this process is completing the required 8-h training to obtain a "buprenorphine waiver" (sometimes called "X-waiver") to prescribe buprenorphine to patients with OUD. This requirement has been cited as a barrier to access to care for patients who were unable to find a waivered buprenorphine prescriber. Nevertheless, it has been shown that psychiatrists who completed buprenorphine training during residency hold more favorable views toward and are more likely to prescribe buprenorphine after training as compared to those who did not complete training.

The mere ability to prescribe buprenorphine, however, is insufficient for competency in the treatment of OUD; residents need practice prescribing to patients in a variety of settings while still in training and under supervision. By role modeling buprenorphine care, faculty can serve as positive examples to trainees of how buprenorphine treatment can be integrated into their future careers. In the absence of buprenorphine-prescribing faculty within one's academic department, psychiatry training programs can forge connections with community or private practice psychiatrists who provide buprenorphine care and provide opportunities for residents to receive ad hoc supervision in this treatment.

\section{Educational Strategies for Teaching Addiction Psychiatry in Community Settings}

Other available options for community-based learning can include community clinics; supported living environments, such as sober housing; mutual-aid/self-help groups; and mandated treatment settings such as court-mandated diversion programs or physicians' health services for healthcare providers with SUD; methadone clinics; syringe exchanges and safe injection sites; and day programs. Local supportive living environments such as sober housing or therapeutic communities may welcome visits from trainees and offer an opportunity to hear directly from clients about their lived experiences with SUD and recovery. Similarly, inviting people in recovery to speak at resident didactics, case conferences, or grand rounds can help residents see SUDs through the eyes of the patient and not just the eyes of the clinician. Peer support providers as colleagues may also offer residents the opportunity to learn from the lived experience of these individuals.

Self-help or mutual aid groups can also be a valuable learning venue available either in person or online. Participation in such groups can help residents gain an appreciation for the patients' experience of these groups, and the exposure to patients in recovery can counterbalance the erroneous impression residents may have from inpatient settings that patients with SUD never improve. Finally, visits to other treatment settings, such as forensic services, drug courts, healthcare providers' health services, or pain management clinics, can help round out the residents' understanding of the scope of available treatment options for individuals with SUD. 
Table 2 Challenges and opportunities for teaching addictions in residency training

\begin{tabular}{|c|c|c|c|}
\hline Setting & Challenges & Opportunities (see also Table 1) & Sample teaching strategies \\
\hline Outpatient clinic & $\begin{array}{l}\text { - Time constraints on comprehensive } \\
\text { evaluation, developing therapeutic } \\
\text { alliance } \\
\text { - Competing clinical priorities (e.g., } \\
\text { identifying comorbid psychiatric } \\
\text { diagnoses vs addressing acute } \\
\text { psychosocial needs) } \\
\text { - Limited availability of } \\
\text { addiction-expert faculty } \\
\text { supervisors } \\
\text { - Reluctance of patients to disclose } \\
\text { full history; pre-contemplative } \\
\text { patients }\end{array}$ & $\begin{array}{l}\text { - Developing relationships over time } \\
\text { - Seeing full spectrum of recovery } \\
\text { - Learning and practicing evidence-based } \\
\text { screening, brief intervention, referral to } \\
\text { treatment } \\
\text { - Learning community-based referral options } \\
\text { - Practicing motivational interviewing to } \\
\text { facilitate behavior change } \\
\text { - Learning psychotherapeutic interventions to } \\
\text { enhance coping skills and promote relapse } \\
\text { prevention } \\
\text { - Providing harm-reduction education (e.g., } \\
\text { safe needle use) } \\
\text { - Gaining experience with medication for } \\
\text { addiction treatment (MAT) for tobacco, } \\
\text { alcohol, and opioid use disorders } \\
\text { - Using telepsychiatry for patients with SUDs } \\
\text { in areas without treatment }\end{array}$ & $\begin{array}{l}\text { - Learning appropriate levels of care and } \\
\text { community disposition options } \\
\text { - Online buprenorphine waiver training } \\
\text { - Training on Screening, Brief } \\
\text { Intervention, and Referral to } \\
\text { Treatment (SBIRT) alongside primary } \\
\text { care colleagues or peer educators }\end{array}$ \\
\hline $\begin{array}{l}\text { Consultation-liaison } \\
\text { service }\end{array}$ & $\begin{array}{l}\text {-Competing acute medical/surgical } \\
\text { needs } \\
\text {-Conflation of SUDs with } \\
\text { psychosocial needs and deferred to } \\
\text { social work } \\
\text {-Limited availability of } \\
\text { addiction-expert faculty } \\
\text { supervisors } \\
\text {-Lack of collaboration with primary } \\
\text { teams to address SUD treatment }\end{array}$ & $\begin{array}{l}\text { - Consulting to patients with SUDs, often in } \\
\text { advance stages of disease with medical or } \\
\text { surgical complications, psychosocial } \\
\text { challenges } \\
\text { - Learning potential legal consequences of } \\
\text { substance use } \\
\text { - Practicing motivational interviewing } \\
\text { - Learning brief interventions } \\
\text { - Diagnosing and treating acute intoxication, } \\
\text { substance withdrawal, substance-induced } \\
\text { delirium, physical complications of } \\
\text { substance use including infectious disease } \\
\text { and organ failure } \\
\text { - Psychoeducation regarding recommended } \\
\text { limits for safe alcohol use and harm } \\
\text { reduction education (e.g., safe needle use) } \\
\text { - Developing skills in buprenorphine } \\
\text { - Collaborating across disciplines between } \\
\text { primary and consulting teams } \\
\text { - Integrating with transplant, oncology, and } \\
\text { pain management clinics }\end{array}$ & $\begin{array}{l}\text { - Bedside teaching from collaborating } \\
\text { and/or integrated teams (pain } \\
\text { medicine, transplant, etc.) }\end{array}$ \\
\hline $\begin{array}{l}\text { Inpatient units (adult } \\
\text { and child) }\end{array}$ & $\begin{array}{l}\text { - Engaging patients in treatment } \\
\text { - Limited availability of } \\
\text { addiction-trained supervising } \\
\text { faculty } \\
\text { - Fast-paced environment and brief } \\
\text { treatment relationship }\end{array}$ & $\begin{array}{l}\text { - Recognizing and treating withdrawal } \\
\text { syndromes (e.g., alcohol, nicotine, } \\
\text { benzodiazepines, cannabis, stimulants) } \\
\text { - Learning systems of care for SUD in the } \\
\text { community (e.g., sober housing, support } \\
\text { groups, intensive outpatient programs, } \\
\text { population-specific resources such as } \\
\text { supported housing for pregnant patients } \\
\text { with SUD) } \\
\text {-Learning difference between } \\
\text { substance-induced vs primary psychiatric } \\
\text { presentations (e.g., major depressive } \\
\text { episode versus cocaine withdrawal) }\end{array}$ & $\begin{array}{l}\text { - Observed interviews (faculty and } \\
\text { resident), two-way mirror } \\
\text { - Brief lectures, in-services, journal clubs } \\
\text { - Faculty demonstrations of MI, alliance } \\
\text { building } \\
\text { - Reflection exercises to consider } \\
\text { countertransference, treatment } \\
\text { pessimism, etc. }\end{array}$ \\
\hline $\begin{array}{l}\text { Emergency } \\
\text { department }\end{array}$ & $\begin{array}{l}\text { - Fast-paced environment } \\
\text { - Brief, short-term patient encounters } \\
\text { - Patients may be pre-contemplative } \\
\text { - Negative countertransference and } \\
\text { provider hopelessness regarding } \\
\text { patients' recovery }\end{array}$ & $\begin{array}{l}\text { - Education on symptoms and treatment of } \\
\text { agitation secondary to substance use, } \\
\text { medical complications of substance use, and } \\
\text { overdose } \\
\text { - Learning levels of care and opportunities } \\
\text { community-based } \\
\text { - Peer teaching to medical or nursing } \\
\text { colleagues regarding SUD } \\
\text { - Initiating buprenorphine and other MAT }\end{array}$ & $\begin{array}{l}\text { - Case-based teaching on symptoms of } \\
\text { intoxication for various substances } \\
\text { - Resident presentations key topics } \\
\text { (stages of change, stigma, or common } \\
\text { countertransference concerns) } \\
\text { - Case conferences }\end{array}$ \\
\hline
\end{tabular}


Table 2 (continued)

\begin{tabular}{llll}
\hline Setting & Challenges & Opportunities (see also Table 1) & Sample teaching strategies \\
\hline Additional & - Lack of addiction resources & Community-based resources: \\
opportunities & in-house & - Correctional and forensic facilities & \\
& - Residential schools \\
& - Intermediate and long-term residential \\
& facilities \\
& - State hospitals \\
& - Group homes \\
& - Nursing homes \\
& - Sober houses \\
& - Homeless shelters \\
& - Community-based practitioner offices \\
& - Support meetings \\
\hline
\end{tabular}

Use of educational venues outside of a program's home clinic or inpatient unit may be as simple as a half-day or daylong visit, or may be developed into full rotations. With any offsite rotation, it is imperative to ensure proper resident supervision is available and provided. Planning on-site supervision with site leadership before implementing a clinical experience is essential.

For programs with limited local resources for SUD education, online training can enhance programs' inhouse and community resources. Online education in SUD is offered through a number of organizations, including Providers Clinical Support System (PCSS). PCSS also offers mentorship through a national network of clinicians with expertise in treating substance use disorders, co-occurring mental disorders, and pain management including discussion forums as well as one-on-one mentoring. Other high-quality online educational material is available through the American Academy of Addiction Psychiatry (AAAP) and American Society of Addiction Medicine (ASAM).

\section{Discussion}

Meeting both the Accreditation Council for Graduate Medical Education training requirements and the overwhelming clinical need for psychiatric expertise in SUDs may seem daunting for any training director. However, many opportunities exist for teaching and training in addictions within structures and services already available to general psychiatry residencies. Training directors may be able to make substantial improvements in addiction programming by trying one or two of the options presented here that are most achievable within their training program.

Instead of focusing on program deficiencies, program directors can empower faculty to recognize SUD teaching moments wherever they occur in clinical and didactic experiences. Teaching opportunities present themselves when seeing a patient with delirium tremens on the CL service, stimulant-induced psychosis on an inpatient psychiatry service, a near opioid overdose in the emergency department, a patient in longer-term recovery in the general psychiatry clinic, or a patient reporting relapse on alcohol via a telehealth visit.

Educators should approach addiction teaching from a dimensional and not a categorical perspective and with a "progress not perfection" mindset. Even if programs lack subspecialized addiction services or trained faculty, making small steps in enriching the educational experience of learners can have a long-term cumulative effect on improving clinical care. In addition to utilizing local resources and teaching opportunities nested within general training settings, help and community can be found by connecting to colleagues and by reaching out to professional organizations such as AAAP and ASAM, as well as tapping into the rich online resources for addiction psychiatry teaching on the AADPRT website. These organizations also provide opportunities for psychiatry residents to present posters/ workshops and apply for awards (i.e., travel) that could help motivate them to consider pursuing fellowship training in addictions.

\section{Declarations}

Adherence with Ethical Standards This paper does not qualify as research and does not involve human subjects, so we did not seek IRB approval.

Disclosures Dr. Schwartz is the chair of the AADPRT Addictions Committee and is a member of the Academic Psychiatry Editorial Board. Dr. Renner receives royalties from the APA for the APA Handbook, "Office-Based Buprenorphine for the Treatment of Opioid Use Disorder." 


\section{References}

1. Substance Abuse and Mental Health Services Administration. Key substance use and mental health indicators in the United States: results from the 2016 National Survey on Drug Use and Health (HHS Publication No. SMA 17-5044, NSDUH Series H-52) [Internet]. 2017 [cited 2020 Oct 19]. Available from: https:// www.samhsa.gov/data.

2. U.S. Department of Health and Human Services (HHS), Office of the Surgeon General. Facing addiction in America: the surgeon general's report on alcohol, drugs, and health. Washington, DC; 2016.

3. Substance Abuse and Mental Health Services Administration. Key substance use and mental health indicators in the United States: results from the 2018 National Survey on Drug Use and Health (HHS Publication No. PEP19-5068, NSDUH Series H-54) [Internet]. 2019 [cited 2020 Oct 16]. Available from: https:// www.samhsa.gov/data.

4. Rakocevic DB, DeJong SM, Saxon AJ, Renner JA, Schwartz AC. A guide for applying to addiction psychiatry fellowship. Acad Psychiatry. 2020;44:135-40.

5. Renner JA. Counteracting the effect of stigma on education for substance use disorders. Focus (Am Psychiatr Publ). 2019;17: 134-40.

6. Schwartz AC, Frank A, Welsh JW, Blankenship K, DeJong SM. Addictions training in general psychiatry training programs: current gaps and barriers. Acad Psychiatry. 2018;42:642-7.

7. Welsh JW, Schwartz AC, DeJong SM. Addictions Training in Child and Adolescent Psychiatry Fellowships. Acad Psychiatry. 2019;43:13-7.

8. Renner JA. How to train residents to identify and treat dual diagnosis patients. Biol Psychiatry. 2004;56:810-6.

9. Diagnostic and statistical manual of mental disorders: DSM-5. 5th ed. American Psychiatric Association; 2013.

10. American Psychiatric Association Work Group on Substance Use Disorders. Practice guidelines for the treatment of patients with substance use disorders, Second Edition. 2006 [cited 2020 Oct 18]; Available from: https://psychiatryonline.org/pb/assets/ raw/sitewide/practice guidelines/guidelines/substanceuse.pdf.

11. Kuerbis A, Sacco P, Blazer DG, Moore AA. Substance abuse among older adults. Clin Geriatr Med. 2014;30:629-54.
12. Rosengren D. Building motivational interviewing skills: a practitioner workbook. 2nd ed. New York: The Guildford Press; 2018.

13. Denning P, Little J. Practicing harm reduction psychotherapy: an alternative approach to addictions. 2nd ed. New York: The Guildford Press; 2012.

14. Oei JL. Alcohol use in pregnancy and its impact on the mother and child. Addiction. 2020;115:2148-63.

15. Silins E, Conigrave KM, Rakvin C, Dobbins T, Curry K. The influence of structured education and clinical experience on the attitudes of medical students towards substance misusers. Drug Alcohol Rev. 2007;26:191-200.

16. Lindsay DL, Hagle H, Lincoln P, Williams J, Luongo PF. Exploring medical students' conceptions of substance use: a follow-up evaluation. Subst Abus. 2017;38:464-7.

17. Avery J, Han BH, Zerbo E, Wu G, Mauer E, Avery J, et al. Changes in psychiatry residents' attitudes towards individuals with substance use disorders over the course of residency training. Am J Addict. 2017;26:75-9.

18. Balasanova AA. Disrupting traditional training to decrease stigma. Clin Teach. 2020;17:1-3.

19. Botticelli MP, Koh HK. Changing the Language of Addiction. JAMA. 2016;316:1361-2.

20. Wakeman SE, Pham-Kanter G, Donelan K. Attitudes, practices, and preparedness to care for patients with substance use disorder: results from a survey of general internists. Subst Abus. 2016;37: 635-41.

21. van Boekel LC, Brouwers EPM, van Weeghel J, Garretsen HFL. Stigma among health professionals towards patients with substance use disorders and its consequences for healthcare delivery: systematic review. Drug Alcohol Depend. 2013;131:23-35.

22. Shorter D, Dermatis H. Addiction training in general psychiatry residency: a national survey. Subst Abus. 2012;33:392-4.

23. Balasanova AA, MacArthur KR, DeLizza AA. "From all walks of life": attending an Alcoholics Anonymous meeting to reduce addiction stigma among medical students. Acad Psychiatry. 2020;44: 714-20.

Publisher's Note Springer Nature remains neutral with regard to jurisdictional claims in published maps and institutional affiliations. 